\title{
Scientific note: mass-nesting of a native bee Hylaeus (Euprosopoides ) ruficeps kalamundae (Cockerell, 1915) (Hymenoptera: Colletidae: Hylaeinae) in polystyrene
}

\author{
Kit S. PRendergast \\ School of Molecular and Life Sciences, Curtin University, Building 311, Brand Drive, Bentley, WA 6102, Australia
}

Received 21 August 2019 - Revised 10 October 2019 - Accepted 7 November 2019

\begin{abstract}
Plastic is pervasive across ecosystems, with polystyrene being a common plastic synthetic material used in buildings. Although polystyrene is used in hive construction for European honeybees and managed megachilids, cavity-nesting colletids have never been documented to nest in such materials. Here, observations of the solitary native bee Hylaeus (Euprosopoides) ruficeps kalamundae mass-nesting in polystyrene insulation boards in a house in Darlington, Western Australia, are reported. This represents the first instance of a Hylaeus species nesting in polystyrene. The abundance of individuals nesting in this material over successive years suggests this behaviour is not detrimental to the fitness of this species; however, experimental studies comparing fitness between polystyrene and natural materials are required. These observations contribute to the recognition that anthropogenic materials are increasingly being used by wild animals.
\end{abstract}

bees / plastic / hylaeine / adaptive flexibility / nesting

Synthetic materials are globally becoming a ubiquitous component of ecosystems, accompanied with a loss of natural materials. Plastics in particular are recognised as an omnipresent part of the Anthropocene (Zalasiewicz et al. 2016). There have been increasing observations of wild animals utilising anthropogenically sourced materials (Hartwig et al. 2007; Pickrell 2012).

Bees have also been observed to make use of anthropogenic resources as nesting habitat. Nesting in mortar appears to be a common phenomenon (Dollin 2019a; Prendergast, personal observation), even with "pest control" services offering eradication (e.g. Koelewyn 2019). Two species of Megachile in the northern hemisphere have been observed to incorporate plastic materials into their nests (MacIvor and Moore 2013): M. rotunda, which typically uses cut plant leaves, has been observed to construct brood cells out

Corresponding author: K. Prendergast,

kitprendergast21@gmail.com

Handling editor: Klaus Hartfelder of pieces cut from polyethylene-based plastic bags, and M. campanulae, which typically uses plant resins in construction of brood cells, has been observed constructing brood cells out of polyurethane-based exterior building sealant. Recently, a nest produced by a megachilid, postulated to be $M$. rotunda, was found to contain three cells constructed entirely out of two types of plastic (Allasino et al. 2019).

The majority of cases of anthropogenic materials being used by native bees has involved megachilids and, to a lesser extent, apids. There have never been observations of hylaeine bees utilising anthropogenic materials as nesting resources. The majority of hylaeine bees nest in premade cavities in wood created by woodboring beetles and, unlike Megachilidae, but characteristic of colletids, line and seal their nests with "cellophane-like" secretions consisting of a mixture of liquid polyesters and silk protein (Almeida 2008).

On 10 January 2019, the author investigated an infestation of native Hylaeus (Euprosopoides) ruficeps kalamundae (Houston 1981) nesting in the polystyrene insulation of a house located in Darlington, Western Australia. Polystyrene insulation panels had been 

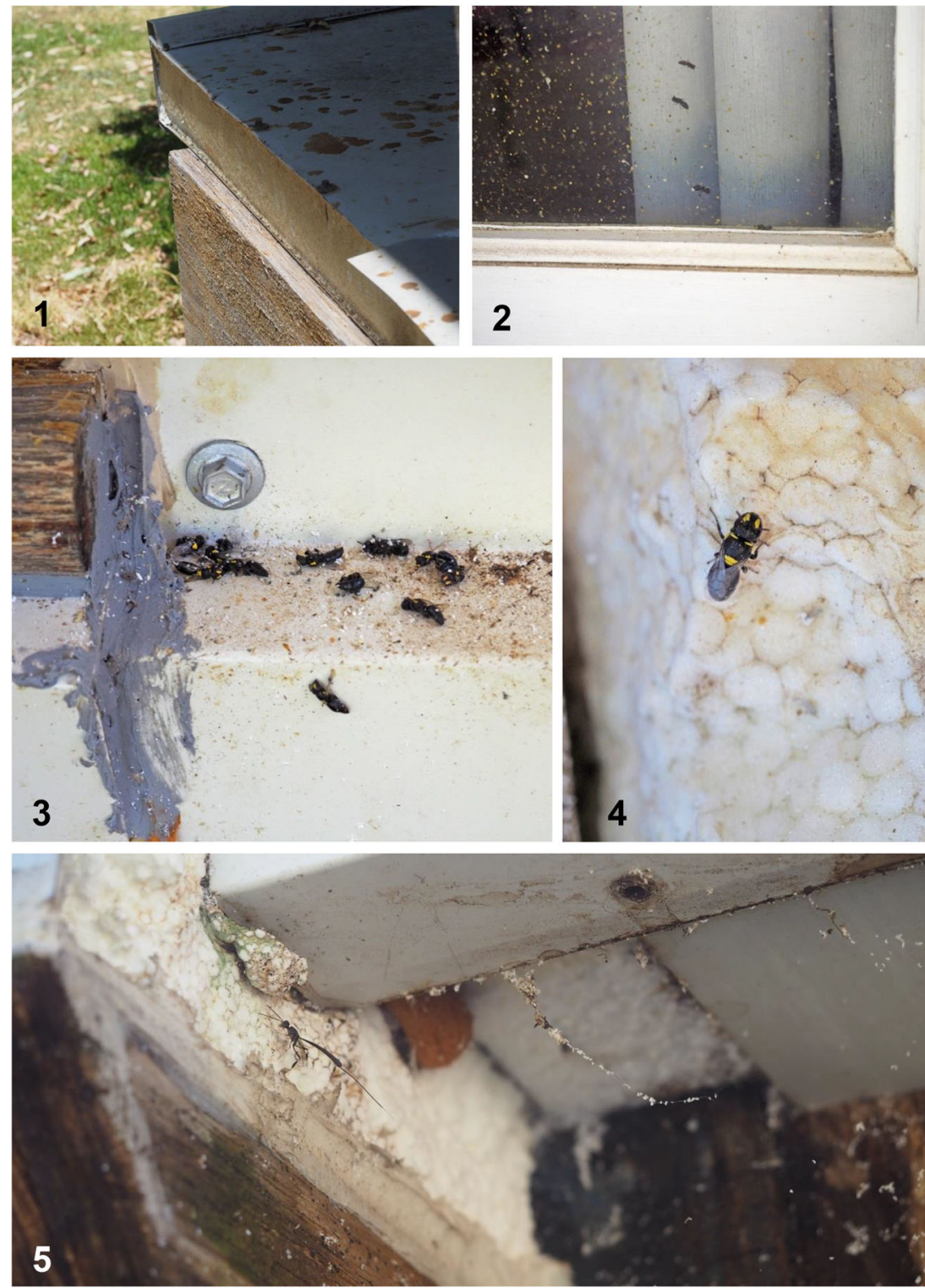

Figures 1-5 1 Polystyrene insulation board. 2 Hylaeus ruficeps kalamundae often entered the house and became trapped and attempted to escape by flying and crawling along the glass door, leaving excrement, with many being unable to escape and perishing. 3 Hylaeus ruficeps kalamundae were entering and exiting to nest in the polystyrene insulation panels through cracks in the boards; entrances sealed over by the owner of the house resulted in an accumulation of dead Hylaeus ruficeps kalamundae that attempted to enter. 4 Female Hylaeus ruficeps kalamundae on the polystyrene block that had been put out to attempt to encourage them to vacate the insulation boards in the house. 5 A female Gasteruption - a predator-inquiline parasitoid wasp - investigating the polystyrene insulation panel where Hylaeus ruficeps kalamundae were nesting. Photos: Kit Prendergast.

installed between the upper and lower levels of the twostory house built by the homeowner (Figures 1, 3, and 5). These insulation panels had been left exposed for about a year before being covered, and during this time, native bees had begun nesting in them. Hundreds of hylaeine bees were observed flying in and out of gaps in the outer boards of the house to access the polystyrene insulation. Bees had also taken to nesting in hardened 
liquid polystyrene that had been used around the corners of windows in the lower level of the house. Although the bees were numerous at the visit, the owner informed the author that in December there would be thousands of bees forming a cloud on the verandah. A block of polystyrene had been placed on the verandah by the owner in an attempt to draw them out of the polystyrene panels in which the female hylaeine bees had begun nesting in as well (Figure 4). Bees had also entered the house from the verandah and were climbing and flying along the glass doors leading out to the verandah (Figure 2). Many had become trapped and perished as a result. No male $H$. kalamundae were observed, and thus, it appears that all observations were of females' nesting, as opposed to progeny emerging, and that mating had occurred elsewhere. The sizeable population attracted a female Gasteruption (Hymenoptera: Gasteruptiidae) (Figure 5).

The property was located in a rural area, surrounded by Eucalyptus and Corymbia calophylla - both major foraging resources for H. kalamundae (Prendergast, personal observation), which would have drawn the bees to the property initially and meant foraging resources were located close to their novel nesting habitat. Although difficult to quantify, it does not appear that the bees were imposed to opt for polyester to nest in due to a dearth of natural nesting substrates.

The sheer number of bees nesting in the polystyrene insulation boards may compromise the integrity of the insulation. It is recommended that homeowners and builders do not leave polystyrene insulation boards exposed for long periods and install them ideally during the cooler months when this species is inactive (Prendergast, personal observation).

These are the first recorded observations of Hylaeus nesting in polystyrene or any other synthetic plastic material. The use of the polystyrene block offered on the verandah suggests a novel material that can be used to encourage such bees to nest, with applications for monitoring purposes, which typically employ trap-nests made from wood with holes drilled in them or PVC pipes filled with hollow reed or bamboo stems (Krombein 1967; MacIvor 2016), and in the rising popularity of "bee hotels" (Prendergast 2019).

Trap-nests have not been installed near Darlington; however, a study by the author (Prendergast 2018) conducted at fourteen sites across Perth over two spring/summer seasons in 2016/2017 and 2017/2018 (totally 10 months) involved installing a total of 112 trap-nests of Eucalyptus marginata wood with five holes of $4 \mathrm{~mm}, 7 \mathrm{~mm}$, and $10 \mathrm{~mm}$ each $10 \mathrm{~cm}$ long. These trap-nests were seldom occupied by $H$. kalamundae: only three nests in the first season and two in the second, all $4 \mathrm{~mm}$ in diameter, were occupied by $H$. kalamundae, across four sites. This is not due to a scarcity of this species: monthly sweepnetting for $3 \mathrm{~h}$ per site by the author resulted in 10 specimens being collected across four sites in 2016/ 2017 and 46 specimens of H. kalamundae at eight sites in 2017/2018. The high attraction to the polyester by $H$. kalamundae suggests that this material may be employed for trap-nesting studies or in studies aimed at collecting multiple individuals of this species.

Consequences for wildlife utilising plastics are often detrimental (Barnes et al. 2009). However, as $H$. kalamundae are not consuming the polyester, the effect of nesting may not be adverse and may even be adaptive. Recently, beekeepers of domesticated European honeybees Apis mellifera have been using hives made from polystyrene (Prendergast, personal observation). Although there are no published studies, beekeepers claim polystyrene hives provide better insulation which improves colony productivity (Australian Honeybee 2019; Roberts 2017). Polystyrene is also used to house megachilids (MacIvor 2016; Pitts-Singer and Cane 2011; Richards 1978). A patent filed for a "leafcutter bee block" constructed from expanded polystyrene beads and vermiculite is claimed to possess "the necessary environmental characteristics attractive to the leafcutter bee namely, dissipation of water while providing a degree of permeability necessary to prevent mould and other harmful effects to the bee larvae."(McCarthy 1988). However, there is also evidence to suggest reproductive output of solitary bees is reduced when nesting in polystyrene compared with wood (Fairey and Lieverse 1986). Further controlled studies comparing fitness of $H$. kalamundae in native wood vs. polystyrene will determine whether nesting in this plastic-based resource is adaptive or an "ecological trap" (Battin 2004).

\section{GENERAL SUMMARY}

Plastic materials are pervasive in environments today and are considered a feature of the Anthropocene. Although plastics are usually considered detrimental to wildlife, there have been recent reports of wild bees using plastic materials in nest construction. Here, the first report of masked bees (genus Hylaeus, family Colletidae) nesting in polystyrene plastic is reported. Hundreds of individuals of the solitary bee Hylaeus (Euprosopoides) ruficeps kalamundae were observed nesting in 
polystyrene plastic weatherboards, and the phenomenon has occurred over a number of years. The fitness consequences are unknown, but it appears that this species displays the ability to utilise this novel material and continue to produce subsequent generations. This is the first report of colletid bees nesting in plastic material.

\section{ACKNOWLEDGEMENTS}

I would like to thank J. Brain for contacting me and allowing me to make the observations of the nesting activity of these bees at his property. I would also like to thank the reviewers for their constructive feedback.

\section{AUTHOR CONTRIBUTIONS}

KP contributed to all observations, species identification, and writing and revising of the paper.

\section{COM P L I A N C E W I T H E T H ICA L STANDARDS}

Conflict of interest The authors declare that they have no conflict of interest.

Note scientifique : nidification en masse d'une abeille indigène Hylaeus (euprosopoides) ruficeps kalamundae (Cockerell, 1915) (Hymenoptera : Colletidae : Hylaeinae) dans le polystyrène.

abeilles / plastique / flexibilité adaptative / nidification.

Eine wissenschaftliche Notiz zum massenhaften Nestbau der einheimischen Biene Hylaeus (euprosopoides) ruficeps kalamundae (Cockerell, 1915) (Hymenoptera: Colletidae: Hylaeinae) in Polystyren.

Bienen / Plastik / Hyalaeine / adaptive Flexibilität / Nestbau.

\section{REFERENCES}

Allasino, M. L., Marrero, H. J., Dorado, J., \& Torretta, J. P. (2019). Scientific note: first global report of a bee nest built only with plastic. Apidologie, 50(2), 230-233. doi:https://doi. org/10.1007/s13592-019-00635-6
Almeida, E. A. (2008). Colletidae nesting biology (Hymenoptera: Apoidea). Apidologie, 39(1), 16-29.

Australian Honeybee. (2019). 10 Benefits of the Paradise Honey Polystyrene Beehives. Retrieved from https://www. australianhoneybee.com.au/swarmpatrol

Barnes, D. K., Galgani, F., Thompson, R. C., \& Barlaz, M. (2009). Accumulation and fragmentation of plastic debris in global environments. Philosophical Transactions of the Royal Society B: Biological Sciences, 364(1526), 1985-1998.

Battin, J. (2004). When good animals love bad habitats: ecological traps and the conservation of animal populations. Conservation Biology, 18(6), 1482-1491.

Dollin, A. (2019a). Are Blue Banded Bees Building in your House? Aussie Bee. Retrieved from https://www.aussiebee.com. au/bluebandedbees-in-house.html

Dollin, A. (2019b). Do you have bees in your house? Aussie Bees. Retrieved from https://www.aussiebee.com.au/bees-in-houses.html

Fairey, D., \& Lieverse, J. (1986). Cell production by the alfalfa leafcutting bee (Megachile rotundata $F$.) in new and used wood and polystyrene nesting materials. Journal of Applied Entomology, 102(1-5), 148-153.

Hartwig, E., Clemens, T., \& Heckroth, M. (2007). Plastic debris as nesting material in a Kittiwake (Rissa tridactyla) colony at the Jammerbugt, Northwest Denmark. Marine Pollution Bulletin, 54(5), 595-597.

Houston, T. F. (1981). A revision of the Australian hylaeine bees (Hymenoptera: Colletidae). II. Australian Journal of Zoology Supplementary Series, 29(80), 1-128.

Koelewyn, S. (2019). Mortar Bees. AusInspect. Retrieved from https://www.ausinspect.com.au/mortar-bees.htm

Krombein, K. V. (1967). Trap-nesting wasps and bees: life histories, nests, and associates. Washington, DC: Smithsonian Press.

MacIvor, J. S. (2016). Cavity-nest boxes for solitary bees: a century of design and research. Apidologie, 48(3), 311-327. doi:https://doi.org/10.1007/s13592-016-0477-z

MacIvor, J. S., \& Moore, A. E. (2013). Bees collect polyurethane and polyethylene plastics as novel nest materials. Ecosphere, 4(12), 1-6.

McCarthy, G. R. (1988). Leaf cutter bee nest block: Google Patents.

Pickrell, J. (2012). Litter-Loving Crab. Sciencemag.org. Retrieved from https://www.sciencemag.org/news/2002/12/litter-lovingcrabs

Pitts-Singer, T. L., \& Cane, J. H. (2011). The alfalfa leafcutting bee, Megachile rotundata: the world's most intensively managed solitary bee. Annual review of entomology, 56, 221-237.

Prendergast, K. (2018). Importance of bushland remnants and honeybee competition for native bees in urban Western Australia. Paper presented at the First Australian Native Bee Conference, Gold Coa st, Q L D . https://australiannativebeeconference.com. au/CONFERENCE-BOOKLET-A4.pdf

Prendergast, K. (2019). Bee Hotels for Native Bees Bee hotel design recommendations, and information on Australian cavity-nesting bees with a focus on bees of south-west Western Australia Retrieved from https://drive.google. com/open?id=1P59uWBfC0NmJGEaSijRk3R4ayAU7OZF2 
Retrieved from https://drive.google.com/open?id=1P59 uWBfC0NmJGEaSijRk3R4ayAU7OZF2

Richards, K. (1978). Comparisons of nesting materials used for the alfalfa leafcutter bee, Megachile pacifica (Hymenoptera: Megachilidae). The Canadian Entomologist, 110(8), 841-846.

Roberts, A. (2017). Plastic hives save hot bees in central Queensland. ABC Capricornia. Retrieved from https://www.abc.net. au/news/2017-01-17/plastic-hives-save-hot-bees-in-centralqueensland/8175952
Zalasiewicz, J., Waters, C. N., do Sul, JAI, Corcoran, P. L., Barnosky, A. D., Cearreta, A., Leinfelder, R. (2016). The geological cycle of plastics and their use as a stratigraphic indicator of the Anthropocene. Anthropocene, 13, 4-17.

Publisher's note Springer Nature remains neutral with regard to jurisdictional claims in published maps and institutional affiliations. 